\title{
LESZEK KUK
}

Uniwersytet Mikołaja Kopernika w Toruniu

ORCID: https://orcid.org/0000-0002-7263-0381

\section{Trójmorze - czyja inicjatywa?}

\section{Three-Seas - whose initiative?}

\section{Abstract}

The "Three-Seas area" project and the activities of the Three-Seas Initiative, i.e. the deepened cooperation of 12 Central European Member States of the European Union, which appeared in 2015, quickly gained considerable popularity in Poland. It has even been recognized as the flagship project of the Polish right wing grouped around the Law and Justice party, which took power in that same year 2015. In the "Three Seas" was seen another emanation of the idea of the so-called Intermarium, present in Polish political tradition since at least 1918.

Meanwhile, the "Three Seas" project was prepared in the autumn of 2014 in the United States by the influential Atlantic Council think tank and included in a comprehensive document entitled "Completing Europe. From the North-South Corridor to Energy, Transportation, and Telecommunications Union Completing Europe". The implementation of its assumptions would not, however, be limited to the modernization and strengthening of infrastructure connections between the aforementioned 12 states located in the NorthSouth belt from Estonia to Croatia and Bulgaria, which were planned to participate in the project. It would also mean the strengthening of their economic ties with the United States, a far-reaching weakening of their economic ties with Russia, and, most importantly, their "independence" in relation to the strong states of the "former Union" with Germany at the fore.

The role of an intermediary in gaining the support of the Central European states was assigned to the new (since February 2015) president of Croatia, Kolinda GrabarKitarović, well known in the decision-making circles of the USA, NATO, and the European 
Union. It quickly recruited the new Polish president, Andrzej Duda, who represents the largest and most pro-American state of the Three Seas countries. These activities made it possible to establish an "organization" on September 29, 2015, during a meeting in New York, attended by 11/12 "leaders" of Central European states and 3 representatives of the Atlantic Council management.

The Three Seas Initiative, defined as the "presidential platform", is constantly expanding the fields of its activity, but it is still regarded as a relatively weak structure with an uncertain future. The sources of its relative internal weakness include, firstly, large differences in the potentials, political positions, and geopolitical orientations of the individual member states of the Initiative, and secondly - the opposing influence of external factors. The United States' aspirations to make the Initiative "transatlantic" have been discreetly opposed since 2018 by the actions of the EU and the German authorities directed towards its "Europeanization", that is, towards the harmonization of its activities with the position of the Union.

Keywords: Three-Seas Initiative, European Union after 2014, Central Europe after 2014, Polish foreign policy after 1989, USA-UE relations

\section{Инициатива трех морей - чья идея?}

\section{Аннотачия}

Проект «Триморья» и деятельность Инициативы трех морей, т.е. углубленное сотрудничество 12 государств Центральной Европы ЕС, появились в 2015 г., быстро приобретая значительную популярность в Польше. Инициатива была даже признана флагманским проектом польского правого крыла, сгруппированного вокруг партии Право и справедливость, которая пришла к власти в том же 2015 г. «Триморье» являлось иной формой воплощения идеи так наз. Междуморья, которая присутствует в польской политической традиции по крайней мере с 1918 г.

Между тем, проект «Трех морей» был подготовлен осенью 2014 г. в США влиятельным тинк-танком Атлантический совет (Atlantic Council) и включен в комплексный документ, озаглавленный «Завершение Европы. От Северо-Южного коридора до энергетики, транспортировки и Телекоммуникационного союза, завершающие Европу». Однако, реализация его основных положений не будет ограничиваться модернизацией и укреплением инфраструктурных связей между вышеупомянутыми 12 государствами, расположенными в севере-южном поясе от Эстонии до Хорватии и Болгарии, которые, как планировалось, должны были принять участие в проекте. Это также означало бы укрепление их экономических связей с США, с далеко идущим ослаблением их экономических контактов с Россией, и, главное, их «независимость» в отношениях с сильными государствами «старого Евросоюза» во главе с Германией. 
Роль посредника в получении поддержки Центрально-европейских стран была предвидена для нового (с февраля 2015 г.) президента Хорватии Колинды Грабар-Китарович - хорошо известной в высших кругах США, НАТО и ЕС. Проект быстро поддержал новый президент Польши Анджей Дуда, который представлял крупнейшуую и проамериканскую страну среди государств Триморья. Эти мероприятия позволили создать «организацию» 29 сентября 2015 г. во время встречи в Нью-Йорке, на которой присутствовали 11 из 12 «лидеров» Центральноевропейских стран и 3 представителя управления Атлантического совета.

Инициатива трех морей, которая определяется как «президентская платформа», постоянно расширяет сферы своей деятельности, но все еще рассматривается как относительно слабая структура с неопределенным будущим. Источники ее внутренней слабости - это, во-первых, большие различия в потенциалах, политических позициях и геополитических ориентациях отдельных государствчленов инициативы, а, во-вторых - противоположное влияние внешних факторов. Стремление США, чтоб инициатива обрела «трансатлантический» характер, стали с 2018 г. осторожно противоречить действиям ЕС и немецких властей, направленных на ее «европеизацию», т.е. гармонизацию ее деятельности с позицией ЕС.

Ключевые слова: Инициатива трех морей (Триморье), Европейский Союз после 2014 г., Центральная Европа после 2014 г., польская внешняя политика после 1989 г., отношения между США и ЕС

\section{Uwagi wprowadzające. Inicjatywa Trójmorza z punktu widzenia polskich koncepcji redefinicji ładu środkowoeuropejskiego}

$\mathrm{P}$ rojekt Inicjatywy Trójmorza ${ }^{1}$ zaakceptowany został w Polsce stosunkowo szybko i łatwo, wręcz uznany za swój, z tego tytułu, że mógł się wydawać kolejną emanacją tzw. orientacji środkowoeuropejskiej. Ta z kolei, funkcjonująca w polskiej tradycji politycznej od dwóch stuleci, po odzyskaniu przez Polskę niepodległości w 1918 roku przejawiała się najczęściej pod nazwą i postacią idei/koncepcji tzw. Międzymorza (Kowal, Orzelska-Stączek, 2019, s. 13).

Orientacja środkowoeuropejska w polityce polskiej winna być zdefiniowana jako zespół koncepcji, idei, postaw i działań zmierzających do

${ }^{1}$ W tym artykule nazwa Trójmorze i Inicjatywa Trójmorza (ta druga jest niewątpliwie bardziej poprawna) używane są wymiennie. W skrócie napotkać można, od jej angielskiej formy Three-Seas Initative, oznaczana bywa jako TSI albo 3SI. 
uczynienia z Europy Środkowej uprzywilejowanego obszaru polskiej obecności i wpływów, zakładających wzmocnienie pozycji Polski i zaktywizowania jej polityki wobec państw i narodów tej części kontynentu, ale jednocześnie wzmacniających dążenia do pomyślnej i korzystnej dla nich redefinicji przestrzeni środkowoeuropejskiej. Silna, wręcz nadrzędna pozycja Polski w przestrzeni środkowoeuropejskiej miała być jednocześnie jej poważnym atutem w stosunkach z mocarstwami. $Z$ geopolitycznego punktu widzenia orientacja środkowoeuropejska nigdy nie była neutralna. Niemal zawsze miała ostrze antyrosyjskie, często (i na ogół równolegle) antyniemieckie, a w głębokim XIX wieku jeszcze incydentalnie antyaustriackie, a nawet antytureckie/antyotomańskie. Podkreślić jeszcze należy pewną jej „komplementarność". Jako orientacja nakierowana w stronę narodów małych i państw drugorzędnych, ustępujących Polsce zarówno pod względem potencjału społeczno-gospodarczego jak i politycznego, miała ona zwykle charakter dopełniający i pomocniczy, wspierając polskie dążenia i polityczne projekty nakierowane w stronę wielkich udziałowców polityki międzynarodowej.

W przeszłości dominowały w refleksji politycznej polskich elit orientacje "równoleżnikowe” - zachodnia/prozachodnia oraz wschodnia, niemal bez wyjątku - prorosyjska. Ta pierwsza uznawana była i jest za naturalną, „narodową” orientację z tytułu przynależności Polski do kręgu zachodniej cywilizacji, a jej intensywność utrzymuje się na stałym, wysokim poziomie z ograniczonymi wahaniami od „niepamiętnych czasów”. Łączność z Zachodem i przynależność do niego uważane były za naturalne źródło siły Polski; bliskość cywilizacyjna nakazywała szukać, często za wygórowaną cenę, sojuszników wśród wielkich nacji zachodnich, co waloryzowało sprawę polską. Do 1940 r. takim najbardziej pożądanym sojusznikiem była z reguły Francja, a po tej dacie oba mocarstwa anglosaskie, przede wszystkim oczywiście USA. Pełny triumf tej orientacji obserwujemy począwszy od $1989 \mathrm{r}$. Składają sią na nią obecnie co najmniej trzy nurty: prounijny, proNATO-wski oraz dominujący proamerykański, dialektycznie się uzupełniające.

Początków nowoczesnej orientacji środkowoeuropejskiej w polskiej myśli politycznej dostarcza jeszcze refleksja Wielkiej Emigracji (Kuk, 1996; Kuk, 2015, s. 104 i n.). Hołdowała ona przede wszystkim orientacji zachodniej; uważała Polskę za jeden z wielkich narodów Europy, zdolny, a nawet predestynowany do tego, by stanąć w jednym szeregu z największymi narodami 
kontynentu, z Francją nieodmiennie na czele. To właśnie Wielka Emigracja jako pierwsza zwróciła uwagę na narody środkowoeuropejskie (głównie Węgrów, Czechów, Rumunów i Serbów), widząc w nich ważnych sojuszników Polski. Począwszy od lat 20. XIX wieku wchodziły one w okres odrodzenia narodowego. To w działaniach Wielkiej Emigracji, zwłaszcza jej skrzydła konserwatywno-liberalnego, tzw. Hotelu Lambert ks. Adama Jerzego Czartoryskiego, dostrzegamy po raz pierwszy w dziejach polskiej myśli politycznej próbę, i to uwieńczoną sukcesem, wypracowania programu polityki środkowoeuropejskiej (Handelsman, 1948-1950; Kukiel, 1955; Skowronek, 1994; Nowak 2001, s. 179-206). Zakładał on najdalej idącą reorganizację polityczną tej przestrzeni, przypominającą w niektórych punktach założenia późniejszego o lat blisko osiemdziesiąt ładu wersalskiego. Rosja miała zostać odepchnięta, a nawet wręcz odseparowana od Europy Środkowej. Polska odbudowana miała być w granicach zbliżonych do przedrozbiorowych. W Europie Środkowej miały powstać silne państwa typu narodowego, pozostające ze sobą w politycznej współpracy, a nawet złączone węzłami federacji lub konfederacji. Polsce automatycznie przypadałoby w tym konglomeracie stanowisko naczelne ${ }^{2}$.

Wielka Wojna dokonała głębokiego przełomu w tym myśleniu. O ile bowiem, mówiąc w uproszczeniu, do Wielkiej Wojny chodziło o zbliżenie i koordynację wysiłków politycznych narodów środkowoeuropejskich, które w ogromnej większości przypadków żyły życiem bezpaństwowym, o tyle po roku 1920 chodziło o koordynację polityk nowopowstałych państw narodowych. Dla pojawienia się i rozprzestrzenienia idei Międzymorza w ścisłym tego słowa znaczeniu punktem startowym były bowiem rozstrzygnięcia pokojowe zamykające I wojnę światową, które dokonały na przełomie drugiego i trzeciego dziesięciolecia XX w. prawdziwie kopernikańskiego przewrotu geopolitycznego w Europie Środkowej - już wówczas mogącej być precyzyjnie rozumianą jako obszar położony między Niemcami i Włochami na zachodzie i Rosją/ZSRR na wschodzie. Przewrót ten polegał generalnie na uwolnieniu

2 Niemal wszyscy piszący o Trójmorzu, przedstawiając historyczne korzenie tej koncepcji, sygnalizują słusznie, że mieści się ona w konwencjach polskiego myślenia o przestrzeni środkowoeuropejskiej. A jego genezę sytuują w okresie następującym tuż po odzyskaniu niepodległości w 1918 r. W przekonaniu, że korzenie te sięgają głęboko w wiek XIX, autor pozwala sobie na zasygnalizowanie powyższych uwag. 
narodowych obszarów poszczególnych narodów środkowoeuropejskich oraz ich samych od obcej dominacji, co nastąpiło poprzez unicestwienie jednego $\mathrm{z}$ trzech wielkich imperiów dzielących między siebie przestrzeń środkowoeuropejską (wielonarodowych Austro-Węgier), a w przypadku dwóch pozostałych, czyli Niemiec i Rosji - poprzez wypchnięcie ich z tej przestrzeni w wyniku ciężkiej klęski, jaką poniosły one w Wielkiej Wojnie ${ }^{3}$.

$\mathrm{Z}$ dnia na dzień nastąpiła szokująca swą szybkością i zasięgiem atomizacja obszaru środkowoeuropejskiego. W miejsce wspomnianych trzech wielkich i potężnych imperiów pojawiła się dziesiątka państw małej i średniej wielkości, słabych, nieokrzepłych, o nikłych często tradycjach państwowych, $\mathrm{z}$ ambicjami pozostającymi w znacznej dysproporcji do ich potencjałów i możliwości, wreszcie często ze sobą skonfliktowanych. Ledwie jedno wśród nich, czyli Polska, osiągało rozmiary porównywalne do czołowych państw zachodnich; było przy tym kontynuacją państwa funkcjonującego uprzednio przez długie wieki. Łączyła te nowe państwa pewna wspólność historycznych doświadczeń, scementowana wspólnością okoliczności historycznych, w jakich się pojawiły bądź odrodziły około roku 1920. W tej sytuacji myśl o koordynacji swych polityk wydawała się im naturalna. Pojawiały się w tym zakresie liczne próby. Równolegle pojawiła się przecież świadomość głębokości funkcjonujących między nimi podziałów.

Europa Środkowa dwukrotnie w wieku XX wybijała się na samodzielność zapewniającą możliwość stanowienia o sobie. Po raz pierwszy tę „autonomię" uzyskała tuż po roku 1918 i cieszyła się nią do roku 1939. Po raz drugi, tuż po roku 1989, czyli ponad 30 lat temu. Jeden i drugi odcinek czasowy wypełnione są refleksją i dyskusją nad Europą Środkową, a w Polsce dodatkowo nad pozycją i rolą własnego kraju w tej przestrzeni. Hasłem wywoławczym tej debaty od dawna jest Międzymorze (Kowal, Orzelska-Stączek, 2019, s. 12 n. ${ }^{4}$ ).

${ }^{3}$ Czwarte $\mathrm{z}$ mocarstw obecnych w przestrzeni środkowoeuropejskiej, czyli Turcja osmańska/otomańska, która, nawiasem mówiąc, obecna była w niej najdłużej, wypchnięta została z tej przestrzeni niedługo przed Wielką Wojną.

4 Autorzy wyróżniają 4 fazy rozwoju refleksji nad Europą Środkową, tytułując ją myśleniem o Międzymorzu, z których pierwszą sytuują w okresie międzywojennym, drugą w okresie II wojny światowej, trzecią - w latach 80. (chodzi o koncepcje wypracowywane przez opozycję antykomunistyczną), a czwartą w okresie po $1989 \mathrm{r}$. 
Dopiero załamanie się bloku wschodniego otworzyło możliwość nie tylko rozwoju nieskrępowanej refleksji nad redefinicją przestrzeni środkowoeuropejskiej, ale również podejmowania działań zmierzających do jej reorganizacji, a nawet ją reorganizującą. W polityce polskiej pojawiło się po roku 1989 podejście regionalistyczne, „nowy regionalizm”s, wyraźnie nakierowany w stronę państw środkowoeuropejskich znajdujących się w zbliżonym położeniu (Bernatowicz, 1994; Zięba, 1992; Zięba, 2004, s. 251-293; Gajewski, 2002, s. 276-313; Kuźniar, 2012). W krótkim czasie, który dzielił upadek struktur i organizacji łączących kraje środkowoeuropejskie ze Związkiem Radzieckim od otwarcia im drogi do struktur euroatlantyckich, zaczęly powstawać dla wypełnienia powstałej luki nowe struktury obejmujące państwa strefy środkowoeuropejskiej. Najważniejszymi z nich były Quadra/Penta/Hexagonale, przekształcone później w Inicjatywę Środkowoeuropejską, Grupa Wyszehradzka, Rada Państw Morza Bałtyckiego i Czarnomorska Współpraca Gospodarcza. Warto przecież zauważyć, że po otwarciu tej drogi proces ten wcale nie zwolnił. Sam szczególnie ważny z naszego punktu widzenia rok 2015 przyniósł „wysyp” inicjatyw w tym zakresie, powołane bowiem zostały do życia aż trzy: trójkąt sławkowski w styczniu, Trójmorze we wrześniu oraz grupa bukareszteńska B9/B-9 w listopadzie.

Trójmorze w tym kontekście wydaje się inicjatywą najważniejszą, najoryginalniejszą, niosącą w sobie największe możliwości, a przy tym dopuszczającą wielość interpretacji. Jednocześnie koncepcja/idea Trójmorza stanowi wariant wysoce oryginalny i odrębny w stosunku do ogółu koncepcji Międzymorza (Czachor, 2020, s. 22; Kowal, Orzelska-Stączek, 2019, s. 13) ${ }^{6}$. Stanowi ich wariant oszczędny, zredukowany, a przede wszystkim wysoce zmodyfikowany; zakłada zbliżenie i bliską współpracę tych państw środkowoeuropejskich, które są państwami członkowskimi Unii Europejskiej. Znaczenie Ukrainy zostało znacznie pomniejszone, rola sprawcza Polski - ograniczona, pozycja USA bardzo wzmocniona (Czachor, 2020, s. 21-23). Czytelna natomiast jest w nim źle skrywana opozycja wobec „starej” Unii

\footnotetext{
5 Termin jest autorstwa ministra Krzysztofa Skubiszewskiego i pochodzi z $1990 \mathrm{r}$.

${ }^{6}$ R. Czachor posuwa się do stwierdzenia, że projekt Trójmorza wręcz zrywa z polską tradycją myślenia o Międzymorzu.
} 
Europejskiej, a dokładniej wobec preponderancji w jej łonie wielkich silnych państw z Niemcami i Francją na czele.

Łączy natomiast Trójmorze $\mathrm{z}$ wszelkimi uprzednimi wariantami „międzymorskimi” wyraźne ostrze antyrosyjskie. W tej perspektywie, równocześnie niemal z Trójmorzem powołana powyżej wspomniana grupa bukareszteńska B9/B-9 zdaje się stanowić jego dopełnienie, wręcz militarny komponent (Stępniewski, 2018, s. 39-40). Tworzą obydwa "ugrupowania” te same państwa, unijne i NATO-wskie, z wyłączeniem trzech: Austrii - niebędącej członkiem NATO oraz dwóch państw wprawdzie członkowskich, ale o nieznacznym potencjale militarnym i odległych od tzw. wschodniej flanki Sojuszu - Słowenii i Chorwacji.

\section{Znaczenie impulsu amerykańskiego do powołania Inicjatywy}

Wspomniana „oryginalność” Inicjatywy Trójmorza tłumaczy się szczególnymi okolicznościami jej powstania. Decydującą albowiem rolę w powołaniu Inicjatywy odegrała dyplomacja Stanów Zjednoczonych. Zauważmy na marginesie, że okoliczność ta w zasadzie umknęła uwadze badaczy ${ }^{7}$, mimo że Inicjatywa budzi duże ich zainteresowanie, a literatura naukowa, jaka powstała na jej temat, jest obfita i wartościowa.

Zaangażowanie się Stanów Zjednoczonych w projekt TSI wpisuje się w kontekst wzrostu znaczenia obszaru środkowoeuropejskiego w polityce tego mocarstwa w obliczu wydarzeń na Ukrainie z przełomu lat 2013 i 2014, których punktem kluczowym była aneksja przez Rosję Krymu. Przedtem, zwłaszcza za pierwszej kadencji prezydenta Baracka Obamy, widoczny był raczej proces odwrotny - słabnięcia zainteresowania USA Europą Środkową (Kowal, Orzelska-Stączek, 2019, s. 54).

Polski MSZ uznaje, że pierwsze, wstępne i przygotowawcze, spotkanie Inicjatywy miało miejsce jeszcze 29 września 2015 r. w Nowym Jorku (Szczyt Inicjatywy Trójmorza $w$ Lublanie, 2019), a zatem jeszcze przed utworzeniem rządów tzw. zjednoczonej prawicy, ale już po objęciu władzy prezydenckiej

7 Zauważmy, że uruchomiona w 2018 r. strona internetowa Inicjatywy (https://3seas. eu/about/threeseasstory) podaje $\mathrm{w}$ tym zakresie podstawowe informacje: o roli Atlantic Council, o jej raporcie „Completing Europe ...”, który miał zainspirować i popchnąć do działania dwoje prezydentów - Chorwacji i Polski. 
przez jej reprezentanta Andrzeja Dudę. Zaangażowanie Polski w Trójmorze rzeczywiście wiąże się wyraźnie z dojściem do władzy tego ugrupowania (stało się nawet jego wręcz „flagowym okrętem”).

Spotkanie z 29 września odbyło się jednak z inicjatywy strony amerykańskiej i przez nią zostało zorganizowane. Wydaje się, że głównym odpowiedzialnym za przygotowanie inicjatywy po stronie amerykańskiej był gen. James L. Jones Jr., wojskowy i polityk bardzo wysokiej rangi ${ }^{8}$. Był on m.in. dowódcą sił NATO w Europie oraz, w latach 2010-2011, doradcą ds. bezpieczeństwa prezydenta Obamy (James L. Jones Jr....). Inicjatywę Trójmorza definiował jako inicjatywę polsko-amerykańską, a informacje, jakich udzielił w wypowiedzi dla „Rzeczpospolitej” z dnia 9 listopada 2018 r., świadczyłyby o tym, że początki amerykańskich prac nad jej przygotowaniem sięgały jesieni 2014 r.: „to wtedy Atlantic Council opracowała dokument, w którym wskazywała, jak bardzo w Europie Środkowej brakuje połączeń północ-południe, nie tylko energetycznych, ale także transportowych i telekomunikacyjnych. Ten region nie był po wojnie objęty Planem Marshalla, a Związek Radziecki z wiadomych przyczyn rozwijał tu wyłącznie połączenia wschód-zachód. Ale dziś apel Atlantic Council przybiera realną formę" (cyt. za: Kowal, Orzelska-Stączek, 2019, s. 56, przyp. 9).

Dokument, o którym mówił gen. Jones Jr., jest obszernym (około 90 stron) fachowym opracowaniem zatytułowanym „Completing Europe. From the North-South Corridor to Energy, Transportation, and Telecommunications Union Completing Europe", dostępnym na stronie internetowej Atlantic Council. Jego powstanie, wyjaśnia się we wstępie (Acknowledgements), nie byłoby możliwe bez wsparcia znanego polskiego przedsiębiorcy i działacza gospodarczego, nieżyjącego już Jana Kulczyka. A we wstępie właściwym (Foreword) czytamy m.in.: Europa (a właściwie Unia Europejska) znajduje się w przełomowym momencie (inflection point) swych dziejów, czego przyczynę stanowią przeciążenia i napięcia zarówno wewnętrzne jak i pochodzące z zewnątrz; wśród tych ostatnich (w liczbie trzech) wymienione jest na pierwszym miejscu zagrożenie ze strony rosnącej w siłę (resurgent) Rosji. Zagrożona jest spójność i odporność Europy/Unii, której najsłabszymi punktami są wolny wzrost gospodarczy oraz ograniczone bezpieczeństwo

${ }^{8}$ Będzie jeszcze uczestniczył w pierwszym, dubrownickim szczycie Trójmorza. 
energetyczne. Słabość Europy/Unii stanowi zagrożenie dla jedności i spójności wspólnoty euroatlantyckiej (transatlantic) (Completing Europe, 2014).

$\mathrm{W}$ tej sytuacji autorzy raportu wysuwają projekt uzupełniający, dopełniający projekty i działania podejmowane przez Unię Europejską mające za cel pogłębienie integracji gospodarczej, a dokładniej - rozbudowę powiązań infrastrukturalnych między krajami środkowoeuropejskimi w trzech podstawowych obszarach: przesyłu surowców energetycznych i energii, sieci transportowej oraz sieci telekomunikacyjnej. W tym celu proponuje się stworzyć zdefiniowany obszar przeznaczony do przyjęcia takich działań w postaci Korytarza Północ-Południe (North-South Corridor), rozpostartego między trzema morzami: Bałtyckim, Adriatyckim i Czarnym. Jego utworzenie przyczyniłoby się do powołania jednego wspólnego europejskiego/ unijnego obszaru gospodarczego (single European market), a w konsekwencji - pełnego urzeczywistnienia wizji zjednoczonej Europy. A w wymiarze ponadeuropejskim Korytarz Północ-Południe winien być rozpatrywany jako kluczowy składnik przyszłego transatlantyckiego/euroatlantyckiego „sojuszu energetycznego”. Z tego tytułu utworzenie Korytarza winno stać się priorytetowym projektem partnerstwa USA-UE.

Lektura tego obszernego dokumentu jest pouczająca, a pewne jego tezy i konkluzje wręcz zaskakujące. Należy go uznać za dokument prezentujący wytyczne dla projektu, który już wkrótce zacznie być określany jako Trójmorze (autorzy raportu nie używają jeszcze tego terminu). Powstał w Ameryce i jest dziełem potężnego i wpływowego amerykańskiego think tanku oraz wiele mniej znanej instytucji środkowoeuropejskiej Central Europe Energy Partners (CEEP) powstałej niewiele wcześniej, bo w 2011 r. Podpisany został przez amerykańskiego generała i jednocześnie prominentnego polityka, wspomnianego Jamesa L. Jonesa Jra, oraz prezesa polskiej grupy Lotos Pawła Olechnowicza. Wśród twórców dokumentu sygnalizowani są głównie Amerykanie (m.in. Ian Brzezinski), Polacy i Węgrzy. Z europejskiego, a jeszcze może bardziej z unijnego punktu widzenia uznać należy, że reprezentatywność środowiska, której raport zawdzięcza swe powstanie, pozostaje ograniczona. A tymczasem jego twórcy uznali się za powołanych do wytyczenia nowych szlaków dla polityki infrastrukturalnej i energetycznej środkowoeuropejskiego podobszaru Unii Europejskiej, a nawet - pośrednio - całej Unii. Więcej, uznali, że zastosowanie się do ich wskazań będzie 
niemal warunkiem wstępnych zharmonizowania polityki energetycznych unijnej i amerykańskiej w przyszłości. Za najbardziej zaskakujący należy uznać to, że kraje środkowoeuropejskie (wszystkie unijne!) konsekwentnie są traktowane w raporcie jako przynależne do zespołu odrębnego, wręcz autonomicznego wobec reszty państw unijnych, wobec unijnego „Zachodu”. Twórców i autorów raportu mało zdaje się zajmować kwestia wzmocnienia powiązań na poziomie energetyki i infrastruktury - tak transportowej, jak i informatycznej - między unijnymi krajami środkowo- z jednej i zachodnioeuropejskimi z drugiej strony. Jak gdyby milcząco uznali te już istniejące za wystarczające. Wydaje się, że rodzący się projekt daje się do pewnego stopnia zakwalifikować jako projekt budowy w wybranych formatach „państwa w państwie".

Przeniesienie projektu do Europy Środkowej nastąpiło w roku 2015 i zostało ułatwione przez dojście do władzy w dwóch państwach przyszłego Trójmorza, położonych na jego przeciwległych biegunach, czyli w Polsce i Chorwacji, polityków reprezentujących twardą proamerykańską prawicę nacjonalistyczną i klerykalną (trzeba zastrzec, że uwaga ta bardziej dotyczy zaplecza politycznego nowego prezydenta Polski niż nowej prezydent Chorwacji), jakimi byli w przypadku Chorwacji Kolinda Grabar-Kitarović, a Polski - Andrzej Duda. Grabar-Kitarović objęła władzę prezydencką w lutym, a jej polski odpowiednik - w sierpniu 2015 r.

Pilotowanie sprawy powierzone zostało prezydent Chorwacji. Kolinda Grabar-Kitarović pozostawała ze wszystkich polityków środkowoeuropejskich tej rangi najlepiej do niej predystynowana. Bardzo dobrze mówiła po angielsku; część swej szkolnej edukacji odbyła w Stanach Zjednoczonych. Dysponowała szerokimi koneksjami i znajomościami zarówno w Unii Europejskiej, jak i w NATO oraz Ameryce. Jej wielką karierę polityczną otworzyło zaangażowanie w proces przyjmowania jej kraju do Unii Europejskiej; w latach 2005-2008 była ministrem spraw zagranicznych oraz ds. integracji europejskiej w rządzie chorwackim, przewodniczyła delegacji chorwackiej w negocjacji akcesyjnych. Od roku 2008 do 2011 była ambasadorem swego kraju w USA, a następnie, w latach 2011-2014 asystentem sekretarza generalnego NATO ds. dyplomacji publicznej (Kolinda Grabar-Kitarović...).

W przeciągu mniej więcej najbliższego roku po zaprzysiężeniu swego polskiego odpowiednika K. Grabar-Kitarović i A. Duda będą się spotykali 
bardzo często: dwukrotnie we wrześniu 2015 r. (na początku tego miesiąca w Krakowie i przy jego końcu w Nowym Jorku), podczas oficjalnej wizyty prez. Grabar-Kitarović w Polsce w styczniu 2016 r. oraz podczas szczytu dubrownickiego przy końcu sierpnia tegoż roku.

Po raz pierwszy zatem spotkali się już na początku września 2015 r., podczas wizyty chorwackiej prezydent w Polsce, dokąd przybyła, by wziąć udział w Forum Ekonomicznym w Krynicy. Z krótkiego komunikatu wynika, że przedmiotem rozmowy dwójki prezydentów była właśnie problematyka zacieśnienia współpracy państw środkowoeuropejskich: „Prezydenci podkreślili znaczenie budowania wspólnoty państw między Bałtykiem, Adriatykiem i Morzem Czarnym, tak aby maksymalnie wykorzystać potencjał polityczny, ekonomiczny i kulturowy tego obszaru" (Spotkanie prezydenta Andrzeja Dudy z prezydent Chorwacji, 2015). Warto przypomnieć w tym kontekście, że w swym orędziu wygłoszonym miesiąc wcześniej, 6 sierpnia 2015 r., przed Zgromadzeniem Narodowym w związku z objęciem władzy prezydenckiej A. Duda podkreślał ważność orientacji środkowoeuropejskiej w polityce polskiej, a nawet sygnalizował wolę dokonania pewnej korekty polskiej polityki zagranicznej idącej w tym właśnie kierunku (mówił o zdynamizowaniu prac Grupy Wyszehradzkiej, pogłębieniu współpracy z państwami środkowoeuropejskimi, zastrzegając przy tym, że winno się dokonywać jej w ramach Unii Europejskiej) (Dahl, 2018, s. 64-65).

Obydwoje prezydentów zdawało się mówić w kwestiach środkowoeuropejskich jednym głosem, a przypomnijmy, że państwa, jakie reprezentowali, z co najmniej jednego ważnego punktu widzenia miały wręcz strategiczne znaczenie dla realizacji celów współpracy „trójmorskiej” zakreślonej w raporcie „Completing Europe”. Chodzi o usytuowanie dwóch najważniejszych terminali LNG, który miał być sprowadzany z USA pod hasłem (i w celu) zwiększania energetycznego bezpieczeństwa Europy. Jeden usytuowany jest w polskim Świnoujściu, a drugi - na południowo-zachodnim krańcu Europy Środkowej - na chorwackiej wyspie Krk (Krk Omišalj). To te dwa państwa, tak różne od siebie geopolitycznym usytuowaniem, wielkością i potencjałami, łączy fakt o kapitalnym znaczeniu: jedno stanowi środkowoeuropejskie wrota od strony Bałtyku, a drugie - od strony Adriatyku. Od strony Morza Czarnego rolę taką mogłaby przyjąć na siebie Ukraina, gdyby była członkiem Unii i gdyby nie utraciła Krymu na rzecz Rosji. 
Analogiczne wątki i motywy obserwujemy podczas kolejnych spotkań dwojga prezydentów, które już będą odbywać się w szerszym gronie. Drugie i decydujące z nich miało miejsce 29 września 2015 r. w Nowym Jorku podczas 70-tej sesji Zgromadzenia Ogólnego ONZ.

\section{Nowojorskie spotkanie 29 września 2015 r.}

W spotkaniu tym, według informacji PAP, udział wzięli obok prezydenta Dudy oraz prezydent Grabar-Kitarović jeszcze „liderzy” dziesięciu państw środkowoeuropejskich. Spotkanie to, które miało się, według powyższej informacji, odbyć z inicjatywy Chorwacji, zdefiniowane zostało jako spotkanie grupy „Adriatyk-Bałtyk-Morze Czarne”, grupującej „kraje Europy Południowej i Środkowo-Wschodniej", dążące do zacieśnienia współpracy gospodarczej między sobą. Wydaje się przecież, że 29 września 2015 r. w Nowym Jorku doszło nie tyle do spotkania grupy już istniejącej, co raczej do powołania jej, chociaż wypowiedź ministra Krzysztofa Szczerskiego stwarza tu pewną konfuzję: „Nie chodzi o tworzenie nowej politycznej, formalnej organizacji, ale o współpracę w ramach istniejących już sieci współpracy" (Nowy Jork..., 2015).

W swej wypowiedzi minister Szczerski dodał jeszcze, że państwom grupy „chodzi o współpracę w trzech obszarach: energetyki, transportowej i telekomunikacyjnej" (Nowy Jork..., 2015). Wprawdzie nie wprowadził pojęcia Korytarza Północ-Południe, ale na określenie zespołu państw angażujących się (przynajmniej in spe) w nowy projekt operował pojęciem „kraje osi Północ-Południe". Założenia tej współpracy zostały prezydentowi Dudzie, wyjaśniał dalej prezydencki minister, przedstawione podczas wspomnianej pierwszej wizyty prezydent Garbar-Kitarović w Polsce, czyli trzy tygodnie przed spotkaniem nowojorskim.

Pełniejszą i bardziej rzeczową informację na temat tego spotkanie odnajdujemy na stronie Atlantic Council (Adriatic-Baltic-Black Sea Leaders Meeting, 2015). Utwierdza to w przekonaniu, że inicjatorzy nowej „struktury” szli za wskazaniami wspomnianego raportu Atlantic Council z listopada 2014 r. Spotkanie to określone zostało jako „nieoficjalne/nieformalne spotkanie na wysokim szczeblu przywódców państw mórz Adriatyckiego, Bałtyckiego i Czarnego (an informal high-level Adriatic-Baltic-Black Sea Leaders'Meeting) 
i odbyło się z inicjatywy prezydent Chorwacji. Ona też przewodniczyła obradom (por. aneks).

W spotkaniu 29 września 2015 r. uczestniczyło 14 przedstawicieli państw i instytucji, prominentnych, ale o nierównej randze. Trzech reprezentowało stronę amerykańską. Byli to Amos Hochstein, Specjalny Wysłannik i Koordynator ds. Międzynarodowych Problemów Energetycznych Departamentu Stanu (Special Envoy and Coordinator for International Energy Affairs, US Department of State) oraz dwóch przedstawicieli Atlantic Council (Frederick Kempe, jej prezes oraz Damon Wilson - wiceprezes).

Pozostałą jedenastkę stanowili sensu stricto „przywódcy” państw środkowoeuropejskich, a dokładniej państw przestrzeni definiowanej jako „[obszar/ area] Adriatyk-Bałtyk-Morze Czarne"/Adriatic-Baltic-Black Sea”. Termin Trójmorze nie pojawia się w dokumencie.

Na liście uczestniczących w spotkaniu reprezentantów państw środkowoeuropejskich nie ma przedstawiciela Łotwy, mimo że jest ona wymieniona jako jeden z 12 krajów reprezentowanych na spotkaniu. Pozostałych 11 państw reprezentowanych było przez (w kolejności ich wymieniania w dokumencie):

- prezydentów (w przypadku 4 państw: Chorwacji, Bułgarii - Rosena Plewnelijewa, Rumunii - Klausa Iohannisa i Polski),

- wicepremiera i ministra spraw zagranicznych i europejskich (w przypadku Słowacji),

- ministrów spraw zagranicznych (w przypadku 4 państw: Litwy, Czech, Estonii, Węgier),

- stałych przedstawicieli przy ONZ (w przypadku 2 państw: Austrii i Słowenii).

Krótkie merytoryczne wprowadzenie, stanowiące uzasadnienie decyzji o zorganizowaniu nowojorskiego spotkania (por. aneks, drugi akapit), zostało dosłownie przeniesione z omawianego powyżej wstępu (Foreword) do raportu „Completing Europe” z jedną nie do końca niewinną różnicą. Wspominając o wyzwaniach/zagrożeniach dla Europy, sprawozdanie kończy na wskazaniu, że wyzwania/zagrożenia (pressures) dzielą się na wewnętrzne i zewnętrzne; nie wylicza tych zewnętrznych, pomijając tym samym wśród nich zagrożenie ze strony Rosji, co zostało uczynione we wstępie do Raportu. Nie pojawia się w nim w ogóle termin „threat”, poprzestaje na właśnie „pressure”. 
Następnie, w akapicie poniżej, znajdujemy informację, że zebrani przywódcy przedyskutowali wyzwania, jakie przed ich regionem i w ogóle przed Europą pojawily się w związku z rosnącą niewydolnością systemów energetycznych, sieci transportowej oraz łączności informatycznej. Dołączony raport „Completing Europe” precyzyjnie i szczegółowo („in details”) przedstawia te problemy - czytamy w następnym zdaniu. Przyjęty on został najpewniej przez zebranych do akceptującej wiadomości i, co najwyżej, stanowił platformę do dyskusji. W końcu odnajdujemy konkluzje znane właśnie z Raportu, mówiące o tym, że uruchomienie Korytarza Północ-Południe w zakresie energetyczno-transportowo-informatycznym jest niezbędne dla stworzenie wspólnego europejskiego rynku oraz całkowitego zjednoczenia Europy i że ze względu na to współpracy między państwami przestrzeni trójmorskiej musi być nadany nowy impuls. Kończy ten krótki dokument zapewnienie, że Atlantic Council gotowa jest do udzielenia wszelkiej pomocy tej „nieformalnej platformie” przywódców 12 krajów, która zebrała się właśnie po raz pierwszy.

Zważywszy na poważne zaangażowanie Stanów Zjednoczonych w powołanie Inicjatywy Trójmorza, przychodzi łatwiej zrozumieć ten nadzwyczajny gest prezydenta Donalda Trumpa, jakim był jego udział w drugim, warszawskim szczycie Trójmorza. Udział ten potwierdzał zaangażowanie nowej administracji w przedsięwzięcie, które było dziełem poprzedniej.

\section{Obciążenia, wyzwania i perspektywy Inicjatywy Trójmorza}

Tak oto doszło do powołania struktury integrującej państwa, przed którymi postawiono pewne wspólne i ważne, a przy tym niełatwe do osiągnięcia cele, ale bardzo od siebie różne, a nawet oddalone. Ich głównym spoiwem jest przynależność do Unii Europejskiej oraz do NATO, w jednym i drugim wypadku - stosunkowo świeżej daty.

O ile różnorodność w sensie wewnętrznego zróżnicowania państw trójmorskiej dwunastki jest oczywista i bezdyskusyjna, o tyle jej potencjał skłania do czynienia mniej jednoznacznych refleksji.

Państwa Trójmorza są liczne, ale z reguły niewielkie zarówno z punktu widzenia rozległości terytorialnej, jak i potencjału demograficznego. $Z$ tej perspektywy (ale też tylko z tej) jedynie Polska, wyraźnie największe 
i najludniejsze z państw dwunastki, jest do pewnego stopnia porównywalna do dużych państw „starej” Unii, czyli Europy Zachodniej. „Małość” państw Trójmorza jest jednocześnie „małością” państw Europy Środkowej, których uśrednione rozmiary oscylują wokół 80-110 tys. $\mathrm{km}^{2}$ terytorium oraz 8-11 mln ludności; w Europie Zachodniej są tylko dwa takie państwa - Grecja i Portugalia i jeszcze należąca do Trójmorza Austria.Z kolei 1/3 jego państw to twory bardzo małe, właściwie pozostające bez odpowiedników w Europie Zachodniej. Takimi są trzy kraje bałtyckie i Słowenia o powierzchni od niespełna 30 do trochę ponad 60 tys. $\mathrm{km}^{2}$ i ludności od niespełna 1,5 do nieco ponad 3 mln mieszkańców. Pod względem wielkości terytorialnej i liczby ludności zróżnicowanie występujące między państwami Trójmorza jest porównywalne do zróżnicowania, jakie obserwujemy w obrębie państwa „starej” Unii, z tą jednak ważną różnicą, że w tym drugim przypadku mamy do czynienia z krajami rozleglejszymi i ludniejszymi.

Również z punktu widzenia zakorzenienia i dziedzictwa cywilizacyjnego poszczególnych narodów podziały funkcjonujące w Europie trójmorskiej wydają się być porównywalne do tych, które występują w „starej” Unii. Wprawdzie w pierwszej dominują narody słowiańskie, a w drugiej romańskie i germańskie, ale i tu, i tu mamy narody wywodzące z trzech wielkich tradycji cywilizacyjnych, czyli katolickiej, protestanckiej oraz wschodniochrześcijańskiej/prawosławnej, a różnice występujące między, dajmy na to, Estonią oraz Bułgarią nie wydają się bardziej odmienne od tych występujących między np. Szwecją a Grecją.

Dopiero na poziomie potencjałów gospodarczych i rozwoju społeczno-gospodarczego różnice stają się bardziej widoczne. Uderzają jednak wiele bardziej przy porównaniu krajów Trójmorza do nienależących do tego „ugrupowania”, co przy porównywaniu państw Trójmorza między sobą. Obszar trójmorski jest z tego punktu widzenia mniej zróżnicowany niż jego nietrójmorski odpowiednik.

I tak, z punktu widzenia wielkości produktu krajowego w cenach bieżących (PPP) per capita w obrębie Trójmorza (z wyłączeniem Austrii) kraje najlepiej rozwinięte osiągają wskaźniki zaledwie nieco ponad dwukrotnie lepsze od państw najsłabszych; z jednej strony mamy zatem Słowenię i Czechy (odpowiednio 23,1 i 21,4 tys. euro na mieszkańca), a z drugiej - Bułgarię i Rumunię (odpowiednio 8,8 i 11,5 tys.). W pozatrójmorskiej części Unii te 
różnice ulegają podwojeniu: w krajach najzamożniejszych (z wyłączeniem Luksemburga) jest to od 72,3 tys. euro w Irlandii, 53,4 w Danii, czy 46,9 w Holandii, podczas gdy w Grecji 17,1 a w Portugalii - 20,8 tys. ${ }^{9}$ Najzamożniejsze z państw Trójmorza osiągają poziom najuboższych krajów Unii nietrójmorskiej.

Zbliżone zróżnicowanie odnajdujemy przy porównywaniu PKB poszczególnych państw ${ }^{10}$, ale tu różnice w obrębie krajów nietrójmorskich są całkowicie porównywalne do tych, jakie dostrzegamy w przypadku państw Inicjatywy. W obrębie tych drugich największą gospodarką, i tym samym największym PKP, dysponuje Polska, której potencjał wyprzedza dwukrotnie dwa następne na liście kraje, czyli Rumunię i Czechy (znowu nie bierzemy Austrii pod uwagę): są to odpowiednio wartości 596/1261, 250/590 oraz 250/436 mld dol. Na drugim biegunie mamy kolejno Estonię (32/49 mld dol.), Łotwę (34/59) oraz Słowenię (54/82). Bezkonkurencyjna pozycja Polski okazuje się jednak słabsza w kontekście gospodarczych osiągów czołowych krajów „starej” Unii, czyli Europy Zachodniej: PKB Niemiec wynosi 3861/4483 mld dol., Francji - 2716/3097, Włoch - 2003/2562 oraz Hiszpanii, jedynego z dużych krajów europejskiego Zachodu, do którego Polska może być porównywana, - 1393/1926.

Oczywiście, powyższe dane nie wyczerpują długiej listy różnic dzielących kraje Inicjatywy w dziedzinie gospodarczej i społecznej. Wskażmy najważniejsze z kolejnych. Wszystkie te kraje, poza jednym (Austrią), należą do NATO. Wszystkie, znowu poza jednym (to znowu Austria), są „nowymi” państwami unijnymi. Połowa $\mathrm{z}$ nich należy do strefy euro. Trzy starają się o to (dwa już przystąpiły do ERM II, trzeci zamierza to uczynić w bliskiej przyszłości; chodzi kolejno o Bułgarię, Chorwację i Rumunię). Trzy nie wykazują zainteresowania takim rozwiązaniem (Polska, Czechy i Węgry). Również trzy są poza strefą Schengen (Bułgaria, Chorwacja i Rumunia). Potrafią wreszcie państwa Trójmorza mieć bardzo odmienny stosunek do głównych problemów międzynarodowych, a nawet do głównych aktorów i zagrożeń dla bezpieczeństwa międzynarodowego. Różnią się w swym

9 Dane Eurostatu. Pod uwagę został wzięty ostatni „normalny” rok przedpandemiczny, czyli 2019. Dane zaokrąglone do pierwszej cyfry po przecinku.

10 Dane zaczerpnięte z CIA Factbook. Countries (dane za rok 2019). Po ukośniku dane PPP. Wszystkie liczby zaokrąglone do jedności. 
stosunku nie tylko do strategicznych celów i kierunku integracji europejskiej czy do polityki i obecności amerykańskiej w Europie, ale także w swym stanowisku wobec Rosji, a nawet Chin (Balcer, 2021, s. 3).

Jeśli chodzi o łączny potencjał państw Trójmorza, wyznaczający w dużej mierze ich pozycję w Unii, również należy przywołać kilka podstawowych wyznaczników. Wprawdzie 12 państw trójmorskich to prawie połowa państw unijnych, ale potem jest już „gorzej”: zajmują one ok. 30\% obszaru Unii, ich ludność stanowi ok. 25\% jej ludności (111 mln); wytwarzają one 20\% PKB Unii (według wskaźnika PPP). Warto przecież zauważyć, że w minionych latach, co najmniej od wejścia do Unii, kraje obecnego Trójmorza mają szybsze tempo wzrostu od państw „starej” Unii; w latach 2015-2019 wyniosło ono $3,5 \%$, podczas gdy dla całej Unii było to $2,1 \%$ (https://3seas.eu/about/ threeseasstory).Zdaniem A. Balcera współpraca w ramach Trójmorza może się przyczynić do przyśpieszenia tempa rozwoju jego państw członkowskich (Balcer, 2021, s. 2) ${ }^{11}$. Ta względna słabość gospodarcza państw Inicjatywy, dobrze widoczna w zestawieniu z potencjałem wielkich państw „starej” Unii, staje się uderzająca dopiero w zestawieniu z siłą gospodarczą dwóch „państw partnerskich” Trójmorza, którymi są dwa największe gospodarcze kolosy obszaru euroatlantyckiego: Stany Zjednoczone i Niemcy.

To ogromne wewnętrzne zróżnicowanie i stosunkowo słaby potencjał własny państw Trójmorza stwarza ryzyko pojawienia się w masowej skali czynnika niezborności i ociężałości wszelkich działań zmierzających do koordynowania współpracy całej nowo powołanej struktury. Z tego punktu widzenia jej sytuacja nie jest jednak całkowicie nieporównywalna z sytuacją panującą w Unii jako całości. Jest to jednak obszar „podwyższonego politycznego ryzyka”, a nawet „szczególnej troski”. Na takim stanowisku zdaje się stać część amerykańskiej klasy politycznej i amerykańskich kręgów decyzyjnych forsujących projekt Trójmorza w uznaniu, że Unia o własnych siłach nie zdoła przeprowadzić projektu pełnej integracji obszaru trójmorskiego (i jednocześnie środkowoeuropejskiego) i że zadanie to wymaga specjalnego zaangażowania Stanów Zjednoczonych mniej więcej tak, jak wymagała tego

11 Powyższe dane liczbowe dotyczące potencjału własnego państw Trójmorza przytaczane są za tym autorem. Szerzej por. Ekonomiczne i kulturowe podstawy Trójmorza, 2017, cz. autorstwa Piotra Eberhardta, s. 20 i n. 
odbudowa Europy Zachodniej po II wojnie światowej. Trzeba przecież pamiętać, że również władze Unii Europejskiej dostrzegły potrzebę podjęcia na szeroką skalę szybkich działań w tym zakresie. Wyraźne pogłębienie refleksji i przyśpieszenie prac nad przyjęciem nowych rozwiązań obserwuje się od co najmniej 2011 r., a kluczowa rola w tej serii przygotowań przypada konkluzjom Rady Europejskiej, przyjętym 24 października 2014 r., które definiowały projekt stworzenia Korytarza Północ-Południe jako „kluczowy” projekt infrastrukturalny w skali całej Unii (of common interest), ale w ograniczeniu do przesyłu gazu ziemnego (EUCO 169/14, 2014, s. 8).

Badacze zgodnie na ogół podkreślają relatywną słabość Inicjatywy Trójmorza i niepewność jej przyszłości (Czachor, 2020, s. 26; Kowal, Orzelska-Stączak, 2019, s. 91; Ukielski, 2018, s. 53, 56). Struktura jest słaba i nieokrzepła, a jej instytucjonalizacja zatrzymała się na niskim pułapie. Brakuje jej solidnych fundamentów instytucjonalnych. Definiowana jako „platforma prezydencka” (w jej szczytach uczestniczy na ogół 8-10 prezydentów $)^{12}$. Inicjatywa nie jest organizacją międzynarodową, nie ma prawnie wiążącego dokument programowego ani organizacyjnego (np. statutu); nie ma ani przewodniczącego/sekretarza generalnego, ani aparatu urzędniczego. Mechanizmy decyzyjne są słabo wyrobione i niesprawne. Funkcjonuje, jako „platforma prezydencka”, od szczytu do szczytu. Można powiedzieć, że cierpi na słabości, które są wspólne dla wszystkich niemal inicjatyw regionalnych obszaru środkowoeuropejskiego, z Grupą Wyszehradzką włącznie.

Na tym tle odnotować przecież trzeba podejmowanie kolejnych prób tworzenia nowych i wzbogacenie istniejących form działalności, idące w parze z, mimo wszystko, postępem instytucjonalizacji struktury. Decydująca przemiana w tym zakresie dokonała się na trzecim szczycie (bukareszteńskim) w 2018 r. Zapowiedziano tam stworzenie listy priorytetowych projektów komunikacyjnych Inicjatywy, Sieci Izb Handlowych Państw Inicjatywy oraz podjęcie prac nad stworzeniem Funduszu Inwestycyjnego Trójmorza $\mathrm{z}$ kapitałem w wysokości 5 mld euro. O powołaniu Forum Biznesu Trójmorza zadecydował jeszcze szczyt warszawski w 2017 r.

12 Zauważana jest ograniczoność i niewydolność tej formuły. Por. Ukielski, 2018, s. 55, przyp. 22. 
Przyszły i dalsze kroki: spotkania na poziomie ministrów (spotkanie ministrów spraw zagranicznych, odbyte w trybie zdalnym z powodu pandemii, miało miejsce w Estonii w 2020 r.). W Polsce z kolei w czerwcu 2021 r. odbyło się Forum Regionów Trójmorza.

Do poczynienia podobnie dwuznacznych ocen skłania analiza gospodarczej aktywności Inicjatywy. W Bukareszcie zaakceptowano listę 49 projektów gospodarczych, do której w Tallinie dwa lata później dorzucono jeszcze 28. Łącznie ich wartość wynosiła 85 mld euro. Liczba projektów proponowanych do realizacji przez poszczególne państwa członkowskie pozostawała w przypadkowym związku z ich potencjałem gospodarczym; zadziwia nikła aktywność w tej materii dwóch silnych gospodarczo w skali Trójmorza państw - Austrii i Czech. Realizacja przyjętych projektów napotykała bardzo często poważne trudności i udawała się tylko częściowo. I tak, z pierwotnej listy 49 projektów do roku 2020 udało się doprowadzić do końca jedynie 3, w 14 osiągnięto postęp nieznaczny, a w 30 - nie osiągnięto żadnego. Na koncie Funduszu Trójmorza udało się do roku 2020 zgromadzić jedynie 1,25 mld euro, czyli 25\% środków przewidzianych (Balcer, 2021, s. 5-8; Ukielski P., 2018, s. 50-53).

Podstawowe zagrożenia dla pomyślnego rozwoju Inicjatywy, a nawet jej dalszej egzystencji, płyną jednak z innych azymutów, a mianowicie politycznego i geopolitycznego. Inicjatywa działa w przestrzeni, gdzie ścierają się siły zewnętrzne poważniejsze od tych, którymi ona dysponuje, czyli USA, wielkich państw „starej” Unii z Niemcami na czele oraz Rosji (ta lista może być w nieodległej przyszłości być wydłużona o Chiny). Wydaje się, że zasadnicze znaczenie dla losów Inicjatywy Trójmorza będzie miało stanowisko Niemiec, które z pewnością w godzinie próby pozyskają dlań wsparcie większości znaczących państw Unii z Francją na czele.

Stosunek Niemiec do Inicjatywy trójmorskiej (Dahl, 2018) ${ }^{13}$ jest ostrożny i pełen dystansu, a nawet nacechowany nieufnością. Inicjatywę od początku uznawano za zagrażającą spójności Unii. Na początku Niemcy wykazywały znikome nią zainteresowanie. Skokowy wzrost tego zainteresowania obserwuje się dopiero od przyjazdu na warszawski szczyt Trójmorza prezydenta

13 Tam próba całościowego ujęcia, zwłaszcza ostatnia część tego artykułu pt. „Republika Federalna Niemiec a Trójmorze”, s. 67-69. 
Trumpa, którego stanowisko wobec Unii Europejskiej oraz europejskiej integracji w Berlinie oceniano wyjątkowo krytycznie. Na następnym szczycie, bukareszteńskim, obecny był minister spraw zagranicznych Niemiec Heiko Maas, a w Lublanie - prezydent Frank-Walter Steinmeier. Analogiczny zwrot obserwujemy w stanowisku władz Unii Europejskiej. W Bukareszcie obecny był Jean-Claude Juncker.

Między stanowiskiem Niemiec oraz ostrożnie i dyskretnie wspierających je władz Unii a stanowiskiem USA (przynajmniej w czasie prezydentury D. Trumpa ${ }^{14}$ ) wspieranych przez kilka krajów tego ugrupowania z Polską na czele ${ }^{15}$ występują zasadnicze różnice doktrynalne.

Państwa Trójmorza w swej większości i wspierające je Stany Zjednoczone stoją bardziej na stanowisku wzmocnienia środkowoeuropejskiego sektora UE w opozycji do komponentu rdzeniowego, czyli państw „dawnej” Unii, niż na stanowisku pogłębienia i zharmonizowania współpracy obydwu tych wielkich, chociaż bardzo nierównych z punktu widzenia ich potencjałów, części Unii. Stoją one jednak, chociaż nie wszystkie z taką samą mocą, przede wszystkim na odmiennych stanowiskach wobec Rosji. Niemcy uznają za pożądane podtrzymanie związków gospodarczych z Rosją oraz, mimo wszelkich przeszkód, podtrzymanie dialogu politycznego z nią. Dobre stosunki z Rosją uważają za atut niemieckiej gospodarki i polityki, za czynnik wzmacniający pozycję Niemiec w Europie, Unii, a nawet w szerszym wymiarze. Zdają się uważać, że dobre stosunki z Rosją budują pozycję Niemiec w Europie/Unii Europejskiej oraz Unii w świecie w obliczu rywalizacji z takimi potęgami jak USA i, coraz częściej, Chiny. Stan chronicznego skonfliktowania z Rosją, czyli taki, jaki występuje w stosunkach unijno-rosyjskich od wiosny 2014 r., uznają za szkodliwy.

Stany Zjednoczone, nie wspominając o państwach środkowoeuropejskich z Polską i państwami bałtyckimi na czele, mają do Rosji stosunek odwrotny.

${ }^{14}$ Do połowy roku 2021 trudno odnaleźć w stanowisku amerykańskim wobec Inicjatywy Trójmorza oznaki zasadniczego zwrotu w stosunku do linii ustalonej jeszcze w roku 2014.

15 Prezydent A. Duda, występując na towarzyszącemu szczytowi bukareszteńskim forum gospodarczym Trójmorza, wypowiedział się jednoznacznie: „[dla Trójmorza] znaczenie współpracy ze Stanami Zjednoczonymi jest kluczowe. Trójmorze jest dla Ameryki strategicznym narzędziem budowania relacji z Europą środkową". Cyt. za: Kowal, Orzelska-Stączak, 2019, s. 70-71. 
Za pożądane uważają możliwie szybkie ograniczenie jej pozycji i politycznych wpływów wszędzie tam, gdzie one jeszcze sięgają, do czego wstępem ma być redukcja wszelkich powiązań gospodarczych łączących kraje unijne, w tym zwłaszcza środkowoeuropejskie, z Rosją. Te ich starania i dążenia rozciągają się przede wszystkim na kluczowy z punktu widzenia interesów Rosji sektor surowców energetycznych, ich produkcję i przesył. Celem jest tu wypchnięcie przy użyciu wszelkich możliwych środków Rosji z europejskiego rynku energetycznego. W ogóle, trwałe osłabienie Rosji, odepchnięcie jej głęboko na wschód i trwałe izolowanie w stosunkach z Europą/Unią wydają się być strategicznymi i długookresowymi celami polityki tych krajów. Chodzi im o podtrzymanie, a nawet pogłębienie procesu „transatlantyzacji” Inicjatywy, tak jak Niemcom o jej „europeizację” ${ }^{\text {. }}$. Tymczasem Inicjatywa wykreowana została po to, by w Europie Środkowej utrzymać, jak to w odniesieniu do Europy Zachodniej w dawno minionej epoce błyskotliwie wskazał lord Ismay, "the Americans in, the Russians out and the Germans down”.

DR HAB. LESZEK KUK, PROF. UMK

Katedra Bezpieczeństwa Społecznego i Kulturowego

Instytut Nauk o Bezpieczeństwie

Wydział Nauk o Polityce i Bezpieczeństwie

Uniwersytet Mikołaja Kopernika w Toruniu

ul. Batorego 39L, 87-100 Toruń

lkuk@umk.pl

16 Dahl idzie daleko w swych konkluzjach i przestrzega, że rozluźnienie więzi łączących kraje Inicjatywy/środkowoeuropejskie z Unią zagroziłoby w dłuższej perspektywie ich bezpieczeństwu „przez stopniowe przesuwanie regionu na wschód w strefę wpływów rosyjskich, co nieuchronnie doprowadziłoby do wzrostu napięć i konfliktów w regionie." (Dahl, 2018, s. 69). 


\section{Bibliografia ${ }^{17}$}

Adriatic-Baltic-Black Sea Leaders Meeting. (2015, 29.10). Pobrane z: https://www.atlanticcouncil.org/commentary/event-recap/adriatic-baltic-back-sea-leaders-meeting.

Balcer, A. (2021). Polska i Trójmorze po Trumpie: szansa na nowe otwarcie? Komentarz. Fundacja Batorego, Forum Idei. Pobrane z: https://www.batory.org.pl/wp-content/ uploads/2021/02/Polska-i-Trojmorze_Komentarz.pdf.

Bernatowicz, G. (1994). Nowy europejski regionalizm. Sprawy Międzynarodowe, 3.

Bieliszczuk, B., Wąsiński, M. (2019). Transformacja energetyczna na obszarze Trójmorza w latach 1988-2018. Polski Przeglad Dyplomatyczny, 2, 87-99.

Completing Europe. From the North-South Corridor to Energy, Transportation, and Telecommunications Union Completing Europe. A joint report by the Atlantic Council and Central Europe Energy Partners in coordination with the Central \& Eastern Europe Development Institute with the support of Grupa LOTOS S.A. and Przedsiębiorstwo Eksploatacji Rurociagów Naftowych S.A., PERN “Przyjaźñ"(2014). Pobrane z: https:// www.ceep.be/www/wp-content/uploads/2014/11/Completing-Europe_Report.pdf.

Czachor, R. (2020). Концепция «Междуморья» во внешней политике Польши. Nowa Polityka Wschodnia, 3(26), 9-26.

Dahl, M. (2018). Inicjatywa Trójmorza z perspektywy niemieckiej. Studia Europejskie, $2,59-72$.

Ekonomiczne i kulturowe podstawy Trójmorza. (2017). Arcana. Kultura, Historia, Polityka, 5(137).

EUCO 169/14 (2014, s. 8.). European Council (23 and 24 October 2014) - Conclusions. Pobrane z: https://www.consilium.europa.eu/media/24561/145397.pdf.

Gajewski, J. (2002). Europa Środkowa w polskiej polityce zagranicznej. W: R. Kuźniar, K. Szczepanik (red.). Polityka zagraniczna RP, 1989-2002 (276-313). Warszawa: ASKON, Fund. Studiów Międzynarodowych.

Handelsman, M. (1948-1950). Adam Czartoryski. T. 1-3. S. Kieniewicz (wyd.). Warszawa: Towarzystwo Naukowe Warszawskie.

James L. Jones Jr. Pobrane z: https://www.csis.org/people/james-l-jones-jr.

Kolinda Grabar-Kitarović. Curriculum vitae. Pobrane z: https://www.un.org/pga/wp-content/uploads/sites/3/2015/03/biography-KGrabar.pdf.

Kowal, P., Orzelska-Stączek. A. (2019). Inicjatywa Trójmorza. Geneza i cele funkcjonowania. Warszawa: ISP PAN.

17 Literatura przedmiotu jest już bogata, nawet w części dotyczącej bezpośrednio Inicjatywy Trójmorza z tym, że znakomicie dominują pozycje prezentujące jej rozwój i działalność w pierwszych 3-4 latach jej istnienia (2015-2018). Dla okresu późniejszego największą wartość uzyskują materiały ze stron internetowych samej Inicjatywy https://3seas.eu (i w ogóle Unii Europejskiej) oraz „narodowych” stron poszczególnych jej krajów, ale także krajów szczególnie zainteresowanych jej rozwojem i kondycją (USA, Niemcy). Poniższa bibliografia ma charakter bardzo selektywny i ogranicza się do podstawowych pozycji oraz do tych, które przywoływane są w przypisach. Ujęte w poniższym wykazie bibliograficznym pozycje $\mathrm{z}$ reguły zawierają dalsze wskazania bibliograficzne. 
Kuk, L. (1996). Orientacja słowiańska w myśli politycznej Wielkiej Emigracji (do wybuchu wojny krymskiej). Geneza, uwarunkowania, podstawowe koncepcje. Toruń: Wydawnictwo UMK.

Kuk, L. (2015). Orientacja środkowoeuropejska w polskiej polityce zagranicznej. Polska w Grupie Wyszehradzkiej. W: E. Alabrudzińska (red.). Między Rosją a Niemcami. Dyplomacja europejska w XX wieku. T. 2: Lata 1945-2000. Toruń: Wydawnictwo Adam Marszałek.

Kukiel, M. (1955). Czartoryski and European Unity, 1770-1861. Princeton: Princeton University Press.

Kuźniar, R. (2012). Polityka zagraniczna III Rzeczypospolitej. Warszawa: Scholar.

Nowak, A. (2001). Europa narodów - wizja księcia Adama Jerzego Czartoryskiego. Polski Przegląd Dyplomatyczny, T. 1, 3, 179-206.

Nowy Jork: prezydent Duda spotkat się z przywódcami Europy Środkowej i Południowej. (2015, 30.09). Pobrane z: https://www.pap.pl/aktualnosci/news\%2C410583\%2Cnowy-jork-prezydent-duda-spotkal-sie-z-przywodcami-europy-srodkowej-i-poludniowej.html.

Orzelska-Stączek, A. (2019). Inicjatywa Trójmorza w świetle teorii realizmu. Polityczne aspekty nowej formy współpracy dwunastu państw. Sprawy Międzynarodowe, T. 72, $1,131-155$.

Skowronek, J. (1994). Adam Jerzy Czartoryski 1770-1861. Warszawa: Państwowe Wydawnictwo Wiedza Powszechna.

Spotkanie prezydenta Andrzeja Dudy z prezydent Chorwacji. (2015, 08.09.). Pobrane z: https://www.prezydent.pl/aktualnosci/wizyty-krajowe/art,22,spotkanie-prezydenta-andrzeja-dudy-z-prezydent-chorwacji-.html.

Stępniewski, T. (2018). Inicjatywa Trójmorza. Uwarunkowania geopolityczne i nowy model regionalnej współpracy. Studia Europejskie, 2, 33-43.

Szczyt Inicjatywy Trójmorza w Lublanie (2019, 06.06.). Pobrane z: https://www.gov.pl/ web/dyplomacja/szczyt-inicjatywy-trojmorza-w-lublanie.

Ukielski, P. (2018). Inicjatywa Trójmorza w polskiej polityce zagranicznej. Studia Europejskie, 2, 45-58.

Zięba, R. (1992). „Nowy regionalizm” w Europie a Polska. Sprawy Międzynarodowe, 1-2, 25-44.

Zięba, R. (2004). Instytucjonalizacja bezpieczeństwa europejskiego: koncepcje - struktury - funkcjonowanie. Warszawa: Scholar.

https://3seas.eu/ - Three Seas. 


\section{ANEKS}

\section{Adriatic-Baltic-Black Sea Leaders Meeting ${ }^{18}$}

At the initiative of Croatian President Kolinda Grabar-Kitarović, the Atlantic Council co-hosted an informal high-level Adriatic-Baltic-Black Sea Leaders' Meeting in New York on Sept. 29, 2015, on the sidelines of the UN General Assembly session.

The meeting of the leaders of twelve European Union member states, which span across the area between the Adriatic Sea, the Black Sea, and the Baltic Sea - Austria, Bulgaria, Croatia, Czech Republic, Estonia, Hungary, Latvia, Lithuania, Poland, Romania, Slovakia, Slovenia - explored the enormous potential to enhance cooperation in infrastructure integration to the benefit of the entire EU and the wider transatlantic community.

Europe is at an inflection point and the vision of a Europe whole, free, and at peace is under pressure from within and outside its frontiers. Reinforcing European integration and tying Central and Eastern Europe closer to the rest of the EU is therefore of critical importance.

The EU's resilience is also at stake and this portends serious implications for the transatlantic community. Economic growth and energy security are the backbones of that resilience, but both are weak spots in the chain mail of Europe.

The assembled leaders discussed challenges in creating the missing energy, transportation, and digital links. A joint report, issued last November by the Atlantic Council and Central Europe Energy Partners entitled "Completing Europe - From the North-South Corridor to Energy, Transportation and Telecommunications Union", presents these challenges in detail. As an integrated set of energy, transportation, and digital links spanning from the Baltic to the Adriatic and Black Seas, the North-South Corridor is critical to the creation of a single European market, a cornerstone to the vision of a united Europe.

The meeting in New York concluded that the momentum behind a comprehensive Adriatic-Baltic-Black Sea area integration, both within and across

18 Adriatic-Baltic-Black Sea Leaders Meeting (2015, 29.10). Pobrane z: https://www. atlanticcouncil.org/commentary/event-recap/adriatic-baltic-back-sea-leaders-meeting. 
the broader European space, has to be reinvigorated. The Atlantic Council remains committed to supporting this process and stands ready to provide assistance to the Adriatic-Baltic-Black Sea Leaders' informal platform in the future to facilitate intergovernmental coordination and cooperation along the corridor, and to engage the business sector on both sides of the Atlantic to attract investment.

The meeting was attended by:

- H.E. Kolinda Grabar-Kitarović, President, Republic of Croatia (Chair)

- H.E. Rosen Plevneliev, President, Republic of Bulgaria

- H.E. Klaus Iohannis, President, Romania

- H.E. Andrzej Duda, President, Republic of Poland

- H.E. Miroslav Lajčak, Deputy Prime Minister and Minister of Foreign and European Affairs, Slovak Republic

- H.E. Linas Linkevičius, Minister of Foreign Affairs, Republic of Lithuania

- H.E. Lubomír Zaorálek, Minister of Foreign Affairs, Czech Republic

- H.E. Marina Kaljurand, Minister of Foreign Affairs, Republic of Estonia

- H.E. Péter Szijjártó, Minister of Foreign Affairs and Trade, Hungary

- H.E. Jan Kickert, Permanent Representative, Permanent Mission of Austria to the United Nations

- H.E. Andrej Logar, Permanent Representative, Permanent Mission of Slovenia to the United Nations

- Mr. Amos Hochstein, Special Envoy and Coordinator for International Energy Affairs, US Department of State

- Mr. Frederick Kempe, President and CEO, Atlantic Council

- Mr. Damon Wilson, Executive Vice President, Atlantic Council 